THE ECONOMICS OF NON-CONVEX ECOSYSTEMS 


\section{THE ECONOMICS OF NON-MARKET GOODS AND RESOURCES}

VOLUME 4

\section{Series Editor: Dr. Ian J. Bateman}

Dr. Ian J. Bateman is Professor of Environmental Economics at the School of Environmental Sciences, University of East Anglia (UEA) and directs the research theme Innovation in Decision Support (Tools and Methods) within the Programme on Environmental Decision Making (PEDM) at the Centre for Social and Economic Research on the Global Environment (CSERGE), UEA. The PEDM is funded by the UK Economic and Social Research Council. Professor Bateman is also a member of the Centre for the Economic and Behavioural Analysis of Risk and Decision (CEBARD) at UEA and Executive Editor of Environmental and Resource Economics, an international journal published in cooperation with the European Association of Environmental and Resource Economists (EAERE).

\section{Aims and Scope}

The volumes which comprise The Economics of Non-Market Goods and Resources series have been specially commissioned to bring a new perspective to the greatest economic challenge facing society in the $21^{\text {st }}$ Century; the successful incorporation of non-market goods within economic decision making. Only by addressing the complexity of the underlying issues raised by such a task can society hope to redirect global economies onto paths of sustainable development. To this end the series combines and contrasts perspectives from environmental, ecological and resource economics and contains a variety of volumes which will appeal to students, researchers, and decision makers at a range of expertise levels. The series will initially address two themes, the first examining the ways in which economists assess the value of nonmarket goods, the second looking at approaches to the sustainable use and management of such goods. These will be supplemented with further texts examining the fundamental theoretical and applied problems raised by public good decision making.

For further information about the series and how to order, please visit our Website http:/www.wkap.nl/series.htm/ENGO 


\title{
The Economics of Non-Convex Ecosystems
}

\author{
Edited by
}

\section{Partha Dasgupta}

Cambridge University, Faculty of Economics, Cambridge, UK

and

\section{Karl-Göran Mäler}

Beijer International Institute of Ecological Economics,

Royal Swedish Academy of Sciences, Stockholm, Sweden 
eBook ISBN: $\quad 1-4020-2515-7$

Print ISBN: $\quad 1-4020-1864-9$

(C)2004 Kluwer Academic Publishers

New York, Boston, Dordrecht, London, Moscow

Print @2004 Kluwer Academic Publishers

Dordrecht

All rights reserved

No part of this eBook may be reproduced or transmitted in any form or by any means, electronic, mechanical, recording, or otherwise, without written consent from the Publisher

Created in the United States of America

Visit Kluwer Online at:

http://kluweronline.com

and Kluwer's eBookstore at:

http://ebooks.kluweronline.com 


\section{Contents}

The Economics of Non-Convex Ecosystems: Introduction P. Dasgupta, K.-G. Mäler

Scale and Scaling in Ecological and Economic Systems

J. Chave, S. Levin

Convex Relationships in Ecosystems Containing Mixtures of Trees and Grass

R.J. Scholes

Managing Systems with Non-convex Positive Feedback

W.A. Brock, D. Starrett

The Economics of Shallow Lakes

K.-G. Mäler, A. Xepapadeas, A. de Zeeuw

Multiple Species Boreal Forests - What Faustmann Missed

A.-S. Crépin

Evaluating Projects and Assessing Sustainable Development in Imperfect Economies

K.J. Arrow, P. Dasgupta, K.-G. Mäler 